Florida International University FIU Digital Commons

$5-12-2017$

\title{
Measuring the Economic Value and Social Impact of Crocodile Tourism in Tarcoles, Costa Rica
}

Ana Lemos

alemo001@fiu.edu

DOI: $10.25148 /$ etd.FIDC001984

Follow this and additional works at: https://digitalcommons.fiu.edu/etd

Part of the Environmental Studies Commons, and the Latin American Studies Commons

\section{Recommended Citation}

Lemos, Ana, "Measuring the Economic Value and Social Impact of Crocodile Tourism in Tarcoles, Costa Rica" (2017). FIU Electronic Theses and Dissertations. 3329.

https://digitalcommons.fiu.edu/etd/3329 


\section{FLORIDA INTERNATIONAL UNIVERSITY}

Miami, Florida

\section{MEASURING THE ECONOMIC VALUE AND SOCIAL IMPACT OF CROCODILE TOURISM IN TARCOLES, COSTA RICA}

A thesis submitted in partial fulfillment of the

requirements for the degree of

MASTER OF SCIENCE

in

ENVIRONMENTAL STUDIES

by

Ana Lemos

2017 
To: Dean Michael R. Heithaus

College of Arts, Sciences and Education

This thesis, written by Ana Lemos, and entitled Measuring the Economic Value and Social Impact of Crocodile Tourism in Tárcoles, Costa Rica, having been approved in respect to style and intellectual content, is referred to you for judgment.

We have read this thesis and recommend that it be approved.

Mahadev Bhat

Elizabeth Anderson

Joel Heinen, Major Professor

Date of Defense: May 12, 2017

The thesis of Ana Lemos is approved.

Dean Michael R. Heithaus College of Arts, Sciences and Education

Andrés G. Gil

Vice President for Research and Economic Development and Dean of the University Graduate School

Florida International University, 2017 


\section{DEDICATION}

I dedicate this thesis to my family- without their sacrifice and love I could not have completed this journey. I am one step closer to being "mi hija, la doctora". 


\section{ACKNOWLEDGMENTS}

I would like to thank my major advisor, Dr. Joel Heinen, for his mentorship and patience throughout this journey. This milestone in my life could not have been achieved if it were not for his support and tough love. I also wish to thank the members of my committee, Dr. Elizabeth Anderson and Dr. Mahadev Baht, for their guidance and continued support. I'd also like to thank Dr. Anderson for convincing me to embrace my inner nerd and dive in to this amazing feat that was graduate school. Another great big thanks goes to the Florida International University (FIU) for all the opportunities it afforded me and all the great adventures I embarked on during this time, especially to all my colleagues and friends in the School of Environment, Arts \& Society and other departments for their support during these years. This work was supported by student travel grants from The Tinker Foundation through FIU's Latin American and Caribbean Studies Program and FIU Foundation student travel awards. The work was approved by FIU's Institutional Research Board for the use of human subjects (IRB-13-0579). 


\section{ABSTRACT OF THE THESIS \\ MEASURING THE ECONOMIC VALUE AND SOCIAL IMPACT OF CROCODILE TOURISM IN TARCOLES, COSTA RICA}

by

Ana Lemos

Florida International University, 2017

Miami, Florida

Professor Joel Heinen, Major Professor

This thesis measures the economic value and social impact of tourism associated with crocodiles (Crocodylus acutus) in Tárcoles, Costa Rica. Crocodile tourism is unique compared to other tourism operations in Costa Rica because it is managed locally and has grown in an organic matter. Qualitative and quantitative data were collected from tourists and key informants who work, directly or indirectly, in crocodile tourism in the region. The results demonstrated that the economic benefits derived from nature-based tourism is an important strength and incentive for $C$. acutus conservation in Tárcoles. Bringing in an estimated USD 5,292,073.81 per year (estimated for 2014) in indirect sales, tourism is one of the main economic drivers and is central to the economic development of the region. Furthermore, understanding the social impacts of the tourism in Tárcoles is vital for ecosystem management and sustainability of the crocodile tourism industry. 


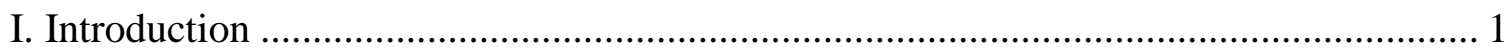

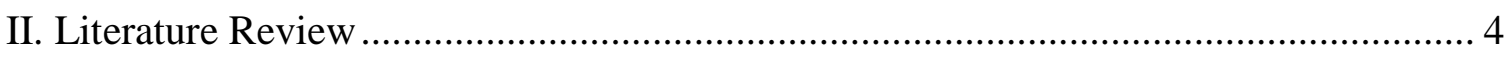

2.1 Tourism, Nature Based Tourism, and Ecotourism........................................... 4

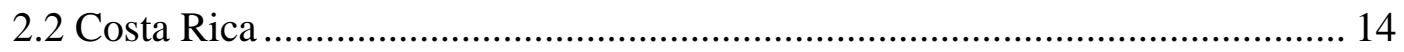

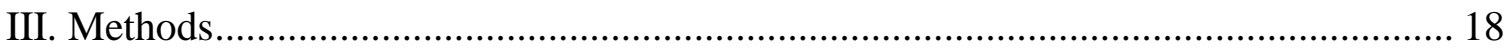

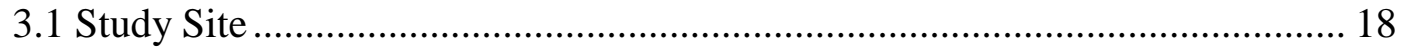

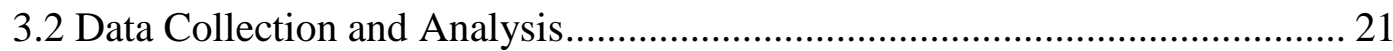

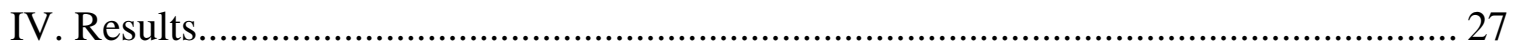

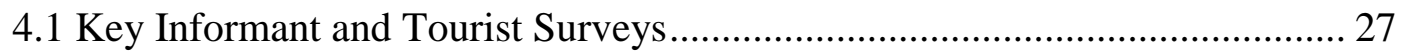

4.2 Economic Impact of Crocodile Tourism...................................................... 32

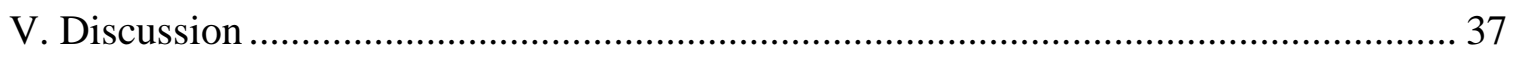

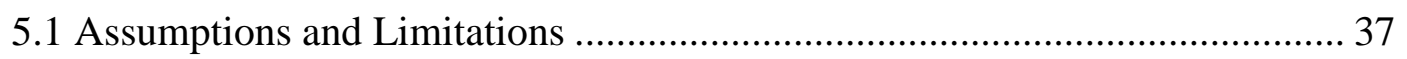

5.2 Crocodiles are part of Tárcoles's Cultural and Economy Identity ................... 38

5.3 Crocodile Tourism is "Ecotourism Lite" ........................................................ 41

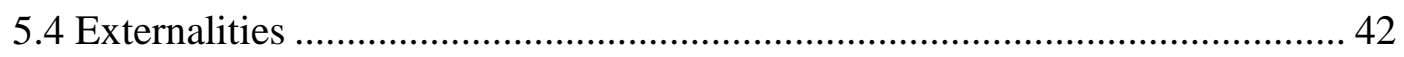

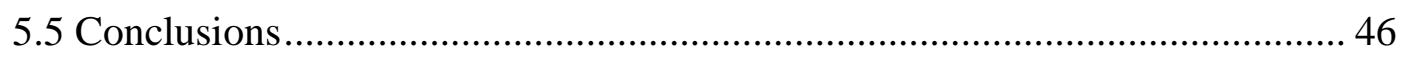

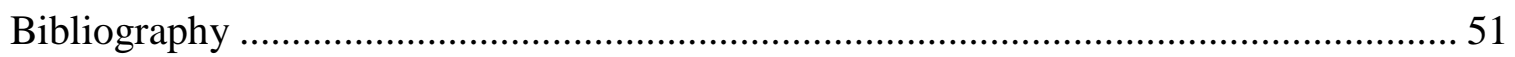




\section{LIST OF TABLES}

TABLE

PAGE

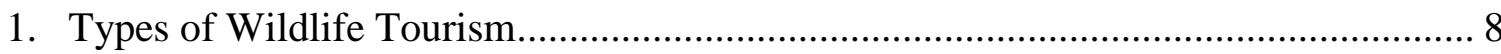

2. Key Informant Interviews Conducted per Sampling Trip ..................................... 27

3. Nationality of Surveyed Tourists at Tárcoles Bridge and Docks ............................ 29

4. Length of Stay in Costa Rica of Surveyed Visitors to Tárcoles Bridge and Docks ... 30

5. Tourist Expenditures on Tárcoles Bridge or Docks (Not Including Crocodile

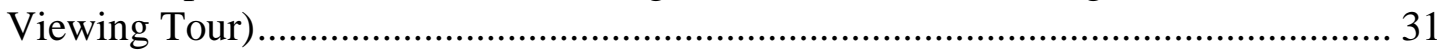

6. Relative Frequency of Tourist Responses to the Question "Do you feel safe on bridge or docks?"

7. Estimated Direct Sales for 2014 in USD Businesses Associated with Crocodile Tourism in Tárcoles ........................................................................................ 35

8. Average Percentage of Operating Costs for Businesses Associated with Crocodile

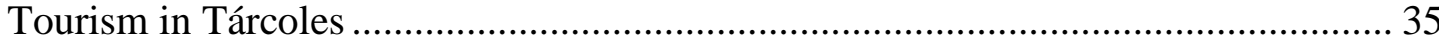

9. Average Percentage of Operating Costs for Businesses Associated with Crocodile

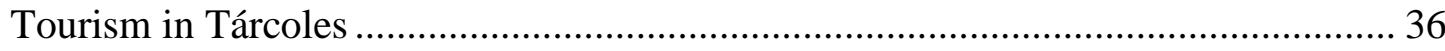

10. Type I Multiplier by Business Category Associated with Crocodile Tourism 36 


\section{Introduction}

Tourisms offers people a temporary escape from the mundane and the chance to have new experiences. Large numbers of people travel the world annually for many reasons and one of the main purposes of travel is to experience natural wonders. Even if it is not at the heart of a trip's itinerary, nature plays a significant role in the enjoyment obtained from many trips. Within the tourism industry, nature-based tourism is the fastest growing sector (Tisdell and Wilson, 2012) and, when done right, can advocate for and support the conservation of the resources upon which it relies.

Many developing countries have set up protected areas and advertise their natural wonders to increase international tourism as part of development plans (e.g., Heinen et al, 2001). Costa Rica, a small Central American country with a population of about 4.9 million (CIA, 2017), is well ahead of most in this regard. The country is well known for its natural beauty and diversity; although its land area is only approximately 51,000 sq. km., it is home to 5 per cent of the world's known biodiversity (Honey, 2008). In 1975 the Costa Rican Institute for Tourism (ICT) identified the nation's flora and fauna as main attractions and subsequently has successfully marketed itself as a premier ecological tourist destination with images of its natural beauty and environmental consciousness (Hearne and Salinas, 2002). Tourism is the most important source of foreign exchange and one of the largest economic drivers in Costa Rica. The total contribution of travel and tourism to gross domestic product (GDP) in 2014 was 12.5\% and is forecasted to increase to $13.2 \%$ by 2025 (WTTC, 2015). Tourism in Costa Rica is clearly thriving and it is considered by some to be "ecotourism's poster child" (Honey, 2008). 
Costa Rica's success can be attributed to the fact that it has the right ingredients to make nature-based tourism work. Socially and politically, the country has a stable democracy, a high standard of living and literacy rate, and generally welcoming people. In terms of environmental management and its flora and fauna, Costa Rica has a large system of functioning national parks and other protected areas (Heinen, 2012), a solid non-governmental organization (NGO) and scientific community, and diverse geography. Also, being just a couple of hours' flight away from the United States and Canada, it is accessible to those large tourist markets.

Nature-based tourism can be attractive as a development strategy because of its focus on a broad range of issues such as sustainability, economic benefits, and the social and political empowerment of local people. In Costa Rica, wildlife viewing is a major tourist attraction. One such attraction that thousands of tourists have experienced in the country is the viewing of the American Crocodile (Crocodylus acutus) in its natural habitat. Costa Rica is home to one of the largest C. acutus populations in the world (Thorbjarnarson et al. 2006). In contrast to many other popular tourist destinations and activities in Costa Rica, crocodile tourism in the Pacific town of Tárcoles is unique. Beginning in the early 1990s, tourism in Tárcoles has grown in an organic manner and is owned and operated by people from nearby communities and not by large tourism corporations located in San Jose or abroad, as in the case of global hotel chains and leisure ship cruises common in the country.

The primary objective of this study is to understand the economic and sociocultural activity crocodile tourism brings to Tárcoles, Costa Rica. A secondary objective is to identify potential threats and opportunities for conservation of C. acutus 
populations in Tárcoles, to understand the local context, and interactions and/or conflicts between people and crocodiles. Some of the questions guiding this work are:

- What is the approximate economic value of crocodile tourism in the Tárcoles region annually?

- How do people in the region benefit economically and socially from crocodile tourism?

- What are the possible threats facing C. acutus in Tárcoles?

- What opportunities exist for the conservation of C. acutus in Tárcoles?

There is a need for enhanced understanding of crocodile tourism in Tárcoles, Costa Rica. Crocodile viewing in Tárcoles is an opportunistic and organic tourism activity that has brought new life and attention to the small fishing town, altering local livelihoods, and possibly the behavior of crocodiles in the area. In addition, increased tourist traffic has piqued the interest of national and international media thereby shining a spotlight on crocodile tourism in the area. As more people have gather on the Tárcoles Bridge to view crocodiles below, and taken crocodile feeding tours, concerns have arisen because of the lack of adequate infrastructure and possible conflicts between crocodiles and people. I examined the economic and sociocultural impact of crocodile tourism in Tárcoles, Costa Rica. To this end, I estimated the annual economic value of crocodile tourism in Tárcoles, identified possible threats and opportunities for the conservation of C. acutus populations in Tárcoles, and studied the local context, interactions and/or conflicts between people and crocodiles. 


\section{Literature Review}

\subsection{Tourism, Nature Based Tourism, and Ecotourism}

The concept of travel as a leisure activity can be traced back to the Greeks and Romans who vacationed at thermal baths and travelled throughout Europe and the Mediterranean. Travel was also part of religious pilgrimages, scientific exploration, geographical conquest, and natural resource exploitation (Honey, 2008). In the eighteenth and nineteenth centuries, European aristocrats and wealthy Americans took "grand tours" of Europe to experience its natural and cultural wonders (Towner, 1985; Towner and Wall, 1991). The industrial revolution brought with it faster modes of transportation (such as railroads) and paid worker vacation time, which allowed "common" people to tour and in 1841, Thomas Cook organized the first tourist excursion (Brendon, 1991). Cook's excursion consisted of a train ride through the English Midlands to temperance rallies and later expanded to organizing tours throughout Europe. Around that same time, American Express started the concept of traveler's checks and money orders, thus making it easier for people to carry money safely (Honey, 2008).

The advent of the airplane and commercial air routes made international tourism more accessible than before. In 1948, Pan American World Airways introduced tourist class and routes between Europe and the United States were opened. Furthermore, in 1957 the introduction of the jet engine which made travel more accessible to the public. Continued innovations in air travel, such as wide bodied high speed airplanes that could more efficiently transport large numbers of people, opened new destinations to travelers. Many of the newly accessible destinations were in the developing world and by the mid 
1970 's, $8 \%$ of vacation travelers traveled from developed to developing countries. The number continued to rise, and in the mid 1990's amounted to $20 \%$ (Honey, 2008).

Tourism is one of the largest industries in the world and is associated with many of the most important sectors of the world's economy. It is also an industry that continues to grow. Over the past six decades, tourism has experienced continued expansion and diversification. Despite occasional shocks resulting from economic shifts and tragic events (e.g., Baral and Heinen, 2006), tourism has had virtually uninterrupted growth over time. Tourism has had an average annual increase of $6.6 \%$ over the past half century (Yeoman et al., 2007) and international tourist arrivals have increased from 25 million globally in 1950 to 278 million in 1980, 674 million in 2000, and 1186 million in 2015 (UNWTO, 2016).

As a result of its growth and massive presence, tourism has become one of the major players in international commerce. Tourism represents the main income sources for many developing countries because tourists rely on many services and infrastructure to achieve their goals and fulfill their needs at a destination. Examples of these are lodging facilities, transportation, and attraction infrastructure. Tourist receipts (defined as expenditures by international visitors on accommodation, food and drink, entertainment, shopping and other services) total earnings was estimated at US\$ 1260 billion worldwide in 2015 (UNWTO, 2016). In addition to receipts earned in destinations, international tourism generated US \$211 billion in exports through international passenger transport services in 2015. International tourism represented 7\% of the world's exports in goods and services in 2016, up from 6\% in 2014 (UNWTO 2016). 
The fastest growing element of the tourism industry is tourism that is done in a natural setting, or nature-based tourism (Tisdell and Wilson, 2012). According to Tisdell and Wilson (2012) "nature-based tourism may be based on visits to natural inanimate objects, on the utilization of natural living things, or on a combination of both." This type of tourism often involves excursions to national parks and wilderness areas or to developing countries where a large portion of the world's biodiversity is concentrated (Christ et al., 2003). Nature-based tourism has many potential benefits and makes a compelling case for wildlife conservation in the long term (such as tangible economic value; Heinen, 1995a). For example, by showing sustainable economic value for wildlife resources, destructive activities such as changes in land use that lead to habitat alternation and poaching can be reduced (Tisdell and Wilson, 2012). Nonetheless, tourism activities that focus on the natural environment may exert many pressures on the resources upon which they rely. Nature-based tourism may lead to overuse of resources and may create risks for the ecosystems and the services they provide (Kuenzi and McNeely, 2008).

Berle (1990) expressed both hope and concern associated with the double-edged sword of nature-based tourism (referred to in the following as "Ecotourism") can be:

"Ecotourism is big business. It can provide foreign exchange and economic reward for the preservation of natural systems and wildlife. But ecotourism also threatens to destroy the resources on which it depends. Tour boats dump garbage in the waters off Antarctica, shutterbugs harass wildlife in National Parks, hordes of us trample fragile areas. This frenzied activity threatens the viability of natural systems. At times we seem to be loving nature to death." 
The development of tourism in some cases may be encouraged because it is one of the major foreign exchange earners in several countries and is viewed by governments as a low-impact development strategy. In the mid to late 1980s many developing countries turned to tourism and "ecotourism" as a foreign exchange earner because it was potentially less destructive than logging, banana cultivation, or commercial fishing. Moreover, in some countries nature-based tourism is the largest component through which earning and employment potential are being generated (Tisdell and Wilson, 2012).

In the absence of wildlife for viewing or nature-based tourism, some groups of tourists may spend fewer days in or completely bypass a destination. Therefore, it is important to care for these resources. Resources such as animals for viewing and trails for hiking are increasingly being used for nature-based tourism worldwide. Examples of this are Monarch butterflies (Danaus plexippus), seasonal migrating birds in Mexico and California, manatees in Florida (King and Heinen, 2004), and the "Big Five" in East Africa (elephant, rhinoceros, buffalo, lion, and leopard), which are well known and attract numerous tourists (Kuenzi and McNeely, 2008). Single species wildlife viewing, such as crocodiles in Australia (Ryan and Harvey, 2000), South Africa, and Costa Rica (this study), and sea turtles in Costa Rica and Mexico are also popular (Heinen, 1995a).

There are several types of and uses for wildlife tourism. Some tourism relies on non-captive wildlife for consumptive use where as other tourist activities rely on captive wildlife for non-consumptive use (Tisdell and Wilson, 2012). Table 1 shows the different types of wildlife tourism with examples (adapted from Tisdell and Wilson 2012). In practice, different types of wildlife tourism may overlap. 


\section{Table 1: Types of Wildlife Tourism}

\begin{tabular}{|l|l|l|}
\hline $\begin{array}{c}\text { Wildlife type which } \\
\text { tourism that relays on }\end{array}$ & $\begin{array}{c}\text { Consumptive or non- } \\
\text { consumptive us of wildlife }\end{array}$ & \multicolumn{1}{c|}{ Example } \\
\hline Non-captive wildlife & Non-consumptive use & Whale watching \\
\hline Non-captive wildlife & Consumptive use & $\begin{array}{l}\text { Recreational hunting or } \\
\text { fishing }\end{array}$ \\
\hline Semi-captive wildlife & Consumptive use & Game or safari hunting parks \\
\hline Semi-captive wildlife & Non-consumptive use & Wildlife refuges \\
\hline Captive wildlife & Non-consumptive use & Traditional zoos \\
\hline Captive wildlife & Consumptive use & Fish farms \\
\hline
\end{tabular}

Adapted from Tisdell and Wilson (2012)

The demand for non-consumptive wildlife tourism has increased during the past four decades because of a rise in nature-based tourism (Tisdell and Wilson, 2012). Additionally, increased urbanization and the rapid decline of wildlife populations and natural habitats have motivated the development of nature-based tourism. The push for this kind of tourism represents a clear shift from the traditional consumptive uses of wildlife resources to one with less impact.

Nature-based tourism can offer local communities a variety od potential benefits. Studies indicate that nature-based tourism can potentially offset conservations costs (Ghate, 2003; Reid-Grant and Bhat, 2009; Heinen et al. 2017; Baral et al. in press), be an alternate source of employment to traditional activities that may not be compatible with conservation (Heinen and Thapa, 1988; Heinen, 1990; Negi and Nautiyal, 2003), create local incentives for conservation (Low and Heinen, 1993; Heinen, 1994; Jamal and Stonza, 2009), and be a driver for economic change and local empowerment that can make communities less dependent on the extraction of natural resources (Billgren and Holmén, 2008). Depending on how they are managed, all forms of wildlife tourism can contribute to and can be compatible with conserving the species being utilized or viewed. 
However, in practice, there are mixed reports on the utility of wildlife tourism to local conservation efforts (Post, 2010).

Wildlife tourism evolves and changes over time in terms of both users and sites where activities take place. Duffus and Dearden (1990) proposed a conceptual framework where they identify the dynamic nature of non-consumptive wildlife tourism. They argue that:

"Through time, a site particularly attractive for wildlife viewing may develop a public image through the growth in publicity and facilities designed to service the visitors who arrive at the area to encounter wildlife. As the facilities expand, this in turn influences the types of individuals who visit a site, the expectations, and the satisfaction derived from the attraction."

There are several types of tourists and the type of tourist that visits an area can change over time. One type are wildlife specialists. These tourists require little infrastructure or interpretive facilities and their pressure is usually absorbable by existing social and ecological systems at the site (Duffus and Dearden, 1990). They are likely to have prior knowledge about the site and wildlife attractions from other specialized explorers and are few enough in number that they require little management intervention. However, as time passes and recognition of the site grows, increased infrastructure and publicity brings generalist wildlife viewers. Examples of this are turtle, whale, and penguin viewing. Tourist presence applies pressure on the social system and ecosystem of the host area, which requires increased management intervention. In the worst of cases, wildlife generalists have little special interest in the site's attraction and rely heavily on 
the development of supportive infrastructure (e.g., Spring Break visitors to Cancun, Mexico).

The demand for nature-based tourism comes from both generalist and specialist tourists, as well as domestic and foreign individuals. The amount of money generated from such tourism varies according to the species viewed. For example, on average, bird watchers, both local and foreign, tend to spend more money than generalists (Sekercioglu, 2002). Nature-based tourism is an important segment of tourism and has grown rapidly in many countries in recent decades. For some countries, as is the case in parts of Africa and Latin America, tourism a major foreign exchange earner. For example, tourism in both Rwanda and South Africa is the fifth major foreign exchange earner. In countries such as Costa Rica, Tanzania, and Kenya, nature-based tourism is one of the major foreign exchange earners.

It is important to note that tourism activities impact the areas where they take place. And tourism creates many externalities. Studies have grouped externalities into three categories: economic, environmental, and socio-cultural (Murphy, 1983; Gunn, 2002; Gursoy et al., 2009). It is often difficult to assess the numerous externalities associated with tourism, particularly the non-economic effects, as no markets for them exist. Because of this, externalities can lead to individual decisions that are not optimal for society at large and they can be quite large.

Tourism externalities can be positive or negative and can affect the welfare of residents of the area where the tourism activity takes place. Some scholars argue that tourism activity tends to bring more costs than benefits to local communities (Chase and 
Alon, 2002). Examples of negative externalities are overcrowding, road congestion, changes in the appearance of the community, degradation of nature, depletion of wildlife, increase in conflicts between locals and tourists, and increase in crime. Positive externalities could be improvements in infrastructure, increase in employment opportunities, and cultural exchanges with tourists.

Negative externalities, such as increased crime and overcrowded beaches, as a result of mass tourism, have led some host countries and tourists to be disillusioned with the idea of tourism as an economic and conservation strategy. Between the 1970s and 1980s, a new field known as "ecotourism" started taking shape and by the early 1990s, the concept had emerged as an alternative for environmentally friendly and socially responsible travel. However, the term "ecotourism" is hard to separate from terms such as "nature-based tourism" or "nature tourism" as all are sometimes used interchangeably. Depending on the work, terms may convey similar or partly overlapping meanings, all of which in some way relate to nature-based tourism while differing in terms of emphasis or underlying philosophy. Although the concept of ecotourism did not originate from within the travel industry, the tourism industry quickly mainstreamed the term.

The tourism industry has come to use "eco-tourism" as a tool to attract environmentally and socially conscious travelers seeking alternatives. The problem comes as some in the industry label any activity that can be done outdoors as "ecotourism." Not all tourism that occurs in nature is not a form of nature-based tourism or considered ecotourism and for this reason, it is important to define ecotourism using other standards. 
Ecotourism is a subset of nature-based tourism. The word "ecotourism" is a derivation of the term "ecological tourism", focusing on the relationship between tourism and living things and their environments. The origin of the term has been attributed by some to Hector Ceballos-Lascurain (1996) who defined it as: "tourism that involves travelling to relatively undisturbed or uncontaminated natural areas with the specific objective of studying, admiring and enjoying the scenery and its wild plants and animals, as well as any existing cultural manifestations (both past and present) found in those areas." Others have traced the term further back to Hetzer (1965) who used it to describe the relationship between tourists and the environments as well as to the cultures in which they interact. He identified four fundamentals that needed to be adhered to for more responsible tourism. These are:

1. Minimum environmental impact.

2. Minimum impact on and maximum respect for host cultures.

3. Maximum economic benefits to the host country.

4. Maximum recreational satisfaction to participating tourists.

Bhatt and Liyakhat (2008) and Nelson (1994) argue that the concept of ecotourism is not new. It is the result of people becoming aware of the harmful effects of mass tourism and the need to create a form of tourism sensitive to the environment, while at the same time providing benefits to local populations. As the destructive effects of mass tourism became widely recognized, many began to look for alternatives. These alternatives were called "responsible," "green," or "low impact" tourism. The first academic work to bring about the idea of a relationship between tourism and 
conservation was Lothar Machura's paper "Nature protection and tourism: with particular reference to Austria" (cited in Fennel, 2015). In the paper, he discussed how tourism, depending on how it was managed, could be incompatible with the protection of nature or could be "a way to express a love of nature."

One of the most widely accepted and comprehensive definitions of ecotourism is provided by Martha Honey, which considers economic, political, and social aspects with environmental concerns. Per Honey (2008), ecotourism needs to have the following seven characteristics:

1. Involves travel to natural destinations.

2. Minimizes impact.

3. Builds environmental awareness.

4. Provides direct financial benefits for conservation.

5. Provides financial benefits and empowerment for local people.

6. Respects local culture.

7. Supports human rights and democratic movements.

Honey defines ecotourism as "travel to fragile, pristine, and usually protected areas that strives to be low impact and (often) small scale. It helps educate the traveler, provides funds for conservation, directly benefits the economic development and political empowerment of local communities and fosters respect for different cultures and human rights" (Honey, 2008). 
The International Ecotourism Society (TIES) defines ecotourism as "responsible travel to natural areas that conserves the environment, sustains the well-being of the local people, and involves interpretation and education" (TIES, 2015). The International Ecotourism Society defines eight Principles of Ecotourism:

1. Minimize physical, social, behavioral, and psychological impacts.

2. Build environmental and cultural awareness and respect.

3. Provide positive experiences for both visitors and hosts.

4. Provide direct financial benefits for conservation.

5. Generate financial benefits for both local people and private industry.

6. Deliver memorable interpretative experiences to visitors that help raise sensitivity to host countries' political, environmental, and social climates.

7. Design, construct and operate low-impact facilities.

8. Recognize the rights and spiritual beliefs of the Indigenous People in the community and work in partnership with them to create empowerment.

\subsection{Costa Rica}

In some countries nature-based tourism remains untapped because of the difficulty of access to sites, political and social instability and restrictions imposed by governments. However, nature-based tourism in Costa Rica is thriving, and the country is considered to be "ecotourism's poster child" (Honey, 2008). Costa Rica is a Central American country well known for its natural beauty and diversity. Even though it is only about 51,000 square kilometers, the country contains 5 per cent of the world's biodiversity. Put into perspective, Costa Rica contains more species of plants and animals 
than the United States and Canada combined (Honey, 2008). It is home to 850 species of birds, 220 species of reptiles, 160 species of amphibians, 280 species of mammals, 130 species of freshwater fish and 9000 species of plants (Evans, 2010). The Daily Mail (a UK-based online newspaper) has heralded Costa Rica as the "perfect destination for adventure seekers, wildlife fans, and lovers of rolling green hills" (Eade, 2011). In 1996, the Costa Rican Tourism Institute (ICT) started a publicity campaign with the slogan "Costa Rica: No artificial ingredients" (Segura, 1998).

In addition to its natural gifts, Costa Rica is seen by outsiders as an oasis within a region plagued with social instability and civil wars. Robert Wesson (1982) referred to Costa Rica as "a civilian island in a Central America otherwise dominated by military and dictatorial governments." The key historical factors that differentiate Costa Rica from its neighbors include being rather isolated and remote from the center of regional politics after the colonial period, the development of relatively equal land distribution, and the dissolution of the military (Miller, 2012). "Costa Rican Exceptionalism" is an integral part of the country's self-identity. It has emerged as one of the guiding principles of the national tourism industry, branding the country as the "Switzerland of Central America" and thus making it very appealing to foreign tourists. In 1987, Costa Rican President Oscar Arias Sanchez received the Nobel Peace Prize, thereby propelling the country further onto the world stage and cementing its image as a safe and peaceful place.

Wildlife viewing is a major tourist attraction in and out of protected areas in Costa Rica. Dolphins, whales, birds, turtles, and monkeys can be seen from different sites throughout the country in varying seasons. Costa Rica has embraced nature-based 
tourism as a strategy for conservation and development (Stem et al, 2003). In 1975, the Costa Rican Institute for Tourism (ICT) identified Costa Rica's flora and fauna as its main attractions, thus giving nature a competitive edge among the tourist community (Campbell, 2002). Since then, Costa Rica has successfully marketed itself as a premier ecological tourist destination with images of its natural beauty and environmental consciousness (Hearne and Salinas, 2002). One of the objectives of the National Plan for Sustainable Tourism 2010-2016 of the Costa Rican Institute of Tourism (ICT) was to maintain the tourism industry as one of the principle drivers of the national economy.

A wildlife attraction that thousands of tourists have experienced in Costa Rica is the viewing of the American Crocodile (Crocodylus acutus) in its natural habitat. Costa Rica is home to one of the largest $C$. acutus populations in the world (Thorbjarnarson et al. 2006). Low-density populations of $C$. acutus are found in wetlands along the Atlantic coast with larger populations found along large rivers of the Pacific coast. Large stable populations occur in the Tempisque, Tárcoles, and San Carlos rivers. The species has been legally protected in Costa Rica since 1975, when the country ratified and began enforcing the Convention on International Trade in Endangered Species of Wild Fauna and Flora (CITES; Heinen, 1995b). Crocodylus acutus is considered an Appendix I species, a species threatened with extinction that is or may be affected by trade. C. acutus is also protected nationally under the Ley de Vida Silvestre, or Wildlife Law (SINAC, 2012).

Crocodilians are a keystone species that play an important role in maintaining biodiversity and ecosystems (Mazzotti et al. 2009). In the 20th century, the commercial 
value of their hides caused many populations to be largely depleted as a result of overharvesting (Thorbjarnarson et al. 2006). In addition to being protected through CITES, C. acutus is currently recognized as a vulnerable species by the IUCN - The World Conservation Union's Red List (Baillie et al., 2004). To date, the species has been recovering in many areas within its historical range (Ponce-Campos et al., 2012) but it is rare to absent in others.

In stark contrast to many other popular tourist destinations in Costa Rica, crocodile tourism in Tárcoles is unique. It has grown in an organic manner and is managed by people from nearby communities. As tourists gathered on the Tárcoles Bridge over the years to view the large congregation of crocodiles below, nearby landowners set up small businesses to cater to them. Furthermore, there are several tour companies that provide crocodile viewing tours by boat in the town of Tárcoles. Per several key informants interviewed for this research, approximately $50 \%$ of the townspeople work directly or indirectly in crocodile tourism or tourism in general. The new business opportunity brought new economic opportunities to the small fishing town. 


\section{Methods}

\subsection{Study Site}

The town of Tárcoles is located about 80 kilometers (about a one hour drive) from the international airport in San Jose on the Pacific coast of Costa Rica (Figure 1). The town is located on the Rio Grande de Tárcoles, which drains a catchment area of 2,169 $\mathrm{km}^{2}$ in the Central Valley of Costa Rica. The basin is surrounded by the Central American Mountain Range with a westward slope to the Pacific Coast. The town is near Carara National Park, an IUCN - World Conservation Union Category II protected area (Heinen, 1995c) popular with international bird watchers. The Tárcoles River is Costa Rica's most contaminated river, and receives approximately $67 \%$ of the country's organic untreated waste. About $250,000 \mathrm{~m}^{3}$ of wastewater are dumped into the Virilla River alone (Blomquist et al, 2005), a tributary of the Tárcoles. The pollution results in the death of fish due to outbreaks of red tide when it reaches the Gulf or Nicoya (Blomquist et al, 2005). High deforestation brought on by agriculture, cattle farming and urbanization enhances soil erosion, which is severe throughout the catchment. 
Figure 1. Map showing the watershed of the Tárcoles River, and the town of Tárcoles, in Costa Rica (from Blomquist et al, 2005).

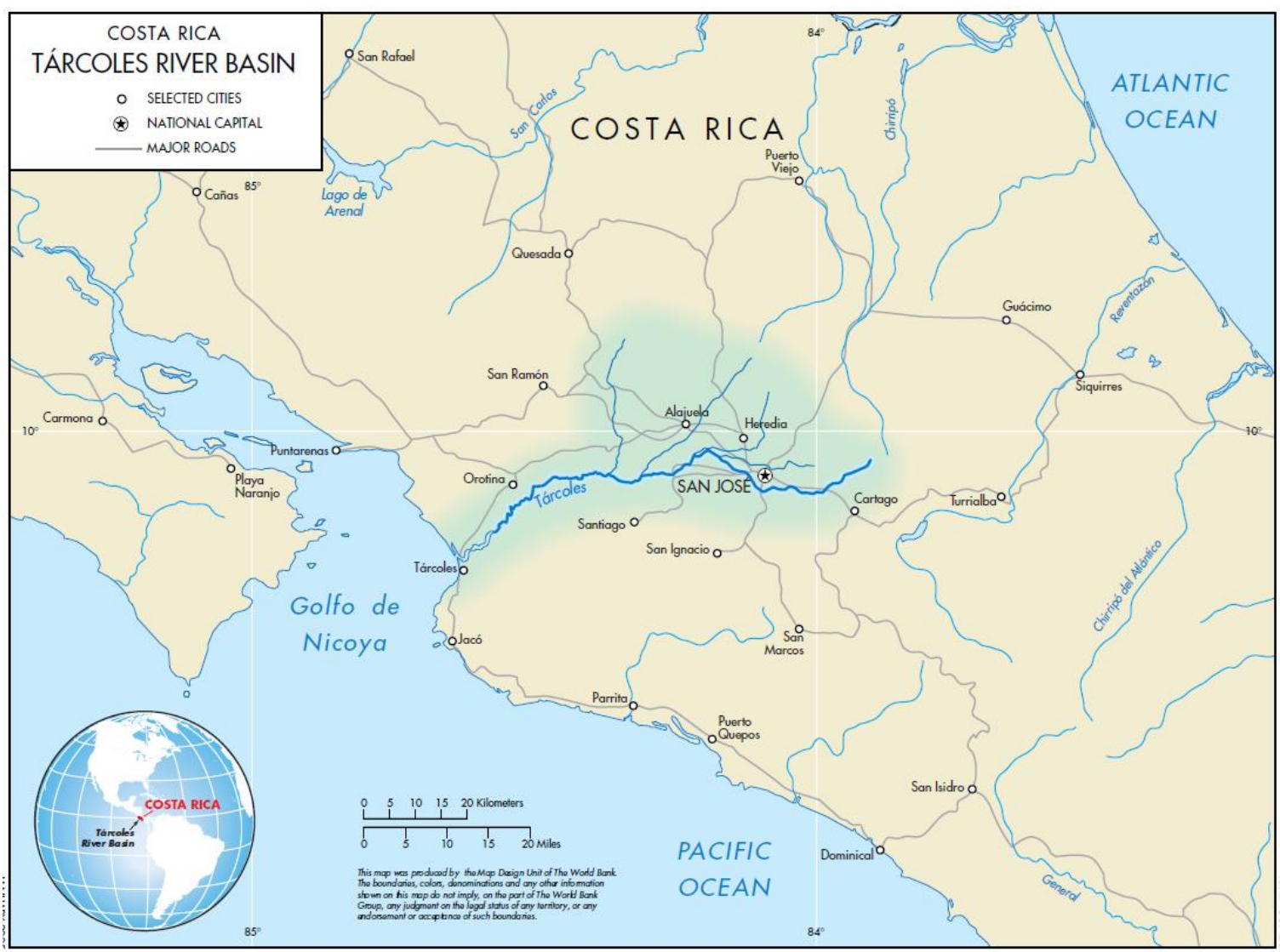

Despite the state of the Tárcoles River, tourists from all over the world stop at the Tárcoles Bridge or take crocodile viewing tours in the area. The tourism activity surrounding crocodiles has grown to be an important economic driver in the region. Approximately 20 adult crocodiles in the lower Tárcoles come to handlers who disembark from boats and stand on shore to hand-feed the crocodiles with fish or chicken. Habituated animals will frequently come completely out of the water to feed. Although the two largest male crocodiles are estimated to be about $5.5 \mathrm{~m}$ total length (18 feet) and many are estimated at four to five meters total length (13 to $16+$ feet), there have (as yet) been no human fatalities or major accidents to the men who feed them. It 
thus appears that $C$. acutus is less predatory on large mammals at the river's edge than other large crocodile species, (e.g., C. niloticus or C. porosus) or at least less likely to perceive humans as food.

There have also been no attacks on small boats in the Tárcoles River, or on people fishing from shore, both common activities in the region. However, there have been 2 recent human fatalities involving crocodiles that were not habituated to hand-feeding. Both victims put themselves in harm's way. One was a young girl who went swimming in an oxbow lake upstream from the bridge and the other was an intoxicated man who either jumped off the Tárcoles Bridge or slid down the western embankment (eyewitness accounts vary) directly into the concentration of large crocodiles below the bridge. He was torn apart and eaten by the crocodiles, and his death - judged to be suicide - was witnessed by several dozen people on the bridge.

The highway from San Jose to the resort town of Jacó crosses over the Tárcoles River and large concentrations of crocodiles congregate under the bridge because people began throwing food, especially raw fish, to them from the bridge. There are many short videos online (e.g., available on YouTube) that show the river, and crocodiles, as they appear from the bridge. As tourists (and crocodiles) gathered, nearby landowners set up small businesses to cater to them. At present, tourists are likely to see upwards of three dozen adult crocodiles from the bridge, and they can choose between two separate fullservice restaurants for meals. Other vendors sell souvenirs (hats, flags, sunglasses, etc.), fruits, drinks and sweets to tourists. Cars and busses regularly stop at the Tárcoles Bridge both coming from and returning to San Jose, with hundreds of passengers on average 
stopping daily year-round from dawn to sunset. Five tour companies, with anywhere from one to six boats that seat 30 to 50 people each, provide crocodile viewing tours on the river from the town of Tárcoles located a few kilometers downstream from the bridge.

While the Costa Rican government is trying to stop hand-feeding, it has been the mainstay of the crocodile boat tours for over 20 years, per local key informants. Several informants interviewed stated that approximately $50 \%$ of the townspeople work in crocodile tourism or tourism in general, at least part-time. The business opportunity brought new economic options to the small town, which was for most of its history a fishing village (Garcia Lozano and Heinen 2016a, b). The marine commercial fishing cooperative remains and is quite active. Artisanal freshwater fishing is permitted in the Tárcoles River, but the river is closed to commercial fishing. The region is also known for cattle ranching, yet ranchers I spoke with indicated that they had little fear of crocodiles killing cattle, although several stated that they keep young calves away from the main channel of the Tárcoles River.

\subsection{Data Collection and Analysis}

I studied crocodile tourism in Tárcoles from 2012 to 2016. For this research, qualitative and quantitative data were collected during five field visits lasting four to five days each to Tárcoles in 2014 and 2015 (January 2014, May 2014, September 2014, November 2014, and August 2015). The sampling framework was chosen to represent low and high tourist seasons, morning and afternoon time periods, and weekends and weekdays. Additionally, from April to June, cruise ship companies such as Norwegian and Celebrity stop at the Puerto Calderas, located $38 \mathrm{~km}$ northwest (roughly a 40-minute 
drive) from the town of Tárcoles and offer their customers the opportunity to visit Tárcoles Bridge and take crocodile tours.

To understand the socio-economic impact of crocodile tourism in Tárcoles, a mixed method approach was used which drew on both qualitative and quantitative methods to enhance, triangulate, and measure the impacts (Heinen, 2010; Creswell and Plano, 2011). Key informant interviews (e.g., Shrestha-Acharya and Heinen, 2006; TerGhazaryan and Heinen, 2006) were conducted with people who work in the tourism industry and short surveys asking about personal expenditures were administered to tourists who stopped on the bridge or who went on a crocodile viewing tour. Key informant interviews were translated and transcribed and common themes were identified. In addition, the local crocodile tour companies provided information about annual ticket sales. That information and market survey interviews with tourists were used to estimate the total annual economic value of crocodile tourism for the year 2014.

For this research, interviewees were divided into 2 groups: (1) tourists who visited the Tárcoles Bridge or the Tárcoles boat dock ( $\mathrm{n}=187)$ and (2) key informants who work directly or indirectly in the crocodile tourism industry $(n=43)$. Those in group 1 were foreign and domestic tourists who stopped on the Tárcoles Bridge briefly or took part in a crocodile viewing tour that started at the Tárcoles boat dock. The key informants (group 2) were business owners (restaurants/fruit stands and gift shops), tour operators, workers for tour operators, and other Tárcoles locals.

Sampling for interviewees in group 1 was done using purposive, convenience sampling (Bernard, 2011). Because of the dynamic nature of the Tárcoles Bridge, survey 
respondents were selected on the basis of who was a tourist (foreign or domestic), who was accessible from the side of the bridge I was located, and whether it was safe to speak with them at that location. The Tárcoles Bridge is located on the Carretera Pacifica where tourists typically less than 20 minutes on the bridge and surrounding areas. In the interest of time and to ensure the safety of the tourists and myself, a survey using the travel cost method (Hotelling, 1949; Bhat et al., 2006) was not administered. Instead, a short survey with four semi-structured questions and one open ended question was conducted. Survey questions and methods for this research were pre-tested by Heinen (personal communication) and a team of researchers who concluded the travel cost survey method was too burdensome and long given the conditions at the study site. The long surveys took 30 minutes or more, and most people stop at the bridge less than the time required and they refused to take long surveys. Thus tourists on the bridge or at the boat docks were asked the following short questions:

1) What country are you from?

2) How long are you staying in Costa Rica? (if applicable)

3) How much money did you spend on the bridge/docks today (not including restaurant expenditures and crocodile tour, is applicable)? How many people do those expenditures include?

4) Do you feel safe on the bridge and its surroundings/docks?

5) Do you have any comments about the crocodiles or this location?

Those surveys typically took less than five minutes and most people who were asked consented to be surveyed. Sampling for key informants in group 2 was non- 
random and purposive (Bernard, 2011), as informants were specifically chosen because of their roles in the community and organizations. In addition to the identification of key informants, a snowball approach was employed where other key informants were suggested by interviewees. Prior to being interviewed, participants in all groups were informed about the general purpose of this research and assured that participation would be voluntary and anonymous. Interviews were recorded using a digital audio recording device and notes were taken in a field notebook. As key informant interviews were conducted mostly in Spanish, they were translated to English and later transcribed into separate documents.

In addition to the tourist surveys and key informant interviews, I directly observed the activities that occurred on the Tárcoles Bridge and the town for two to three day periods during each of the five research trips in 2014 and 2015 (above). Observations allowed me to better understand the dynamics of the location and corroborate responses regarding tourist expenditures. I also did frequent walks around town to note changes in infrastructure, population, and services (such as new shops, restaurants, etc.) and I reviewed publicly available reports on tourism in Costa Rica from the World Travel \& Tourism Council (WTTC) and the Instituto Costarricense de Turismo (ICT).

The Tárcoles Bridge is not an official tourist destination, therefore there are no entrances or turnstiles that track the number of visitors per day. For this reason, a mixed methods approach involving key informant interviews and direct observation was used to estimate the number of tourists who stop on the bridge daily, disaggregated by low or high tourist season. Key informants noted that because the bulk of tourists are foreign, 
most of them were on vacation so there is no noticeable difference in numbers of visitors seen on weekends compared to weekdays. This was confirmed through personal observation of the flow of tourists on the various days.

Tourism establishments were divided into 4 categories: (1) souvenir and fruit stands on the Tárcoles Bridge, (2) restaurants on the Tárcoles Bridge, (3) crocodile tour operators in Tárcoles that operate year-round, and (4) crocodile tour operators in Tárcoles that do not operate year-round. I calculated the annual total direct sales for each tourism establishment in categories 1 and 2 using the following formula:

\section{$\mathrm{ADS}=(($ DVE $\times$ DV $) \times$ HS $)+(($ DVE $\times$ DV $) \times$ LS $)$}

ADS is the Annual Direct Sales for categories 1 and 2, DVE is estimated daily visitor expenditure (e.g., souvenirs, food, drinks), DV is the estimated number of visitors per day per tourist season, and HS and LS are the number of days in the high and low tourism season in 2014, respectively.

Key informants who worked specifically running the crocodile tours in Tárcoles were interviewed regarding their business. From their responses, estimates on how many boat trips per day they conducted in each tourist season (high and low) in 2014, how many people per boat would take the tour per season, and how much the typical tourist would pay for the trip, were all calculated. Various attempts were made to get more precise information from the administrators who worked in tour operator offices, but due to tax and privacy concerns such attempts were unsuccessful. The annual direct sales from crocodile tours (ADSCT) for each operator was added to calculate the total annual 
revenue from crocodile tours in Tárcoles. I estimated the annual direct sales from crocodile tours for each crocodile tour operator using the following formula:

\section{$\operatorname{ADSCT}=($ DIH $\times$ HS $)+($ DIL $\times$ LS $)$}

ADSCT is the annual direct sales for crocodile tourism operators in categories 3 and 4, DIH is the estimated Daily High Season Income, which is the number of people per trip during high season multiplied by the number of trips per day during high season, DIL is Daily Low Season Income which is the number of people per trip during low season multiplied by the number of trips per day during low season, and HS and LS are the number of days in the high and low tourism season in 2014.

In addition to direct sales calculations, economic impacts of crocodile tourism activity can be further analyzed using economic multipliers. The multiplier effect takes into consideration dollars that enter the local economy that are redistributed through purchase of local goods and services, residential and commercial construction, and other expenditures (Stynes et al, 2000). The United States National Park Service (Fish, 2009) uses the Money Generation Model 2 to assess economic impact of national park visitor spending on local economies (Stynes et al, 2000) and has been used to measure economic impact on Volcan Poás National Park in Costa Rica (Aguirre, 2008). For this study, I used the MGM2 method and calculated the Type I multiplier as not enough information was collected to calculate the Induced sales amount needed for the Type II multiplier. The MGM2 Type I multiplier is calculated as follows:

\section{Type I multiplier $=($ Direct sales + Indirect sales $) /$ Direct sales.}


Direct sales refer to the amount of total sales made directly to tourists in the area and indirect sales refers to the operating costs (or purchases) incurred by shops or tourism companies in order to provide goods and services to tourists.

\section{Results}

\subsection{Key Informant and Tourist Surveys}

Throughout this study, 69 separate key informant interviews were conducted with 43 different persons. Several informants were interviewed more than once during the various sampling trips to get new information and perspectives, or to clarify previous answers, and some informants were interviewed simultaneously (such is the case with Tourism police officers at the Tárcoles Bridge as they were stationed together). Approximately 40 hours of interviews were recorded for this research with tourism operators, workers on the Tárcoles Bridge, law enforcement, tourism guides, and other stakeholders in Tárcoles. See Table 2 for a list of key informant categories and number of hours each informant was interviewed disaggregated by sampling trip.

Table 2: Key Informant Interviews Conducted per Sampling Trip

\begin{tabular}{|c|c|c|c|c|c|}
\hline $\begin{array}{c}\text { Sampling Trip } \\
\text { Date }\end{array}$ & $\begin{array}{c}\text { Tourism } \\
\text { Operators } \\
\text { Interviewed }\end{array}$ & $\begin{array}{c}\text { Workers on } \\
\text { Bridge } \\
\text { Interviewed }\end{array}$ & $\begin{array}{c}\text { Police } \\
\text { Officers } \\
\text { Interviewed }\end{array}$ & $\begin{array}{c}\text { Independent } \\
\text { Tour Guides } \\
\text { Interviewed }\end{array}$ & $\begin{array}{c}\text { Tárcoles } \\
\text { Other } \\
\text { Interviewed }\end{array}$ \\
\hline April 2013 & 2 & 0 & 0 & 0 & 0 \\
\hline January 2014 & 4 & 7 & 1 & 2 & 2 \\
\hline May 2014 & 4 & 10 & 2 & 2 & 1 \\
\hline September 2014 & 9 & 0 & 0 & 0 & 4 \\
\hline November 2014 & 3 & 5 & 2 & 0 & 0 \\
\hline August 2015 & 2 & 5 & 2 & 0 & 0 \\
\hline
\end{tabular}




\begin{tabular}{|c|r|r|r|r|}
\hline $\begin{array}{c}\text { Sampling } \\
\text { Trip Date }\end{array}$ & $\begin{array}{c}\text { Number of } \\
\text { interview } \\
\text { hours }\end{array}$ & $\begin{array}{c}\text { Number of } \\
\text { persons } \\
\text { interviewed }\end{array}$ & $\begin{array}{c}\text { Number } \\
\text { of new } \\
\text { interviews }\end{array}$ & $\begin{array}{c}\text { Number of } \\
\text { persons repeat } \\
\text { interviewed }\end{array}$ \\
\hline April 2013 & 3 & 2 & 2 & 0 \\
\hline January 2014 & 9.24 & 16 & 16 & 0 \\
\hline May 2014 & 8.166 & 19 & 11 & 8 \\
\hline September 2014 & 11.666 & 13 & 10 & 8 \\
\hline November 2014 & 5.07 & 10 & 2 & 7 \\
\hline August 2015 & 2.826 & 9 & 2 & 26 \\
\hline TOTAL & 39.968 & 69 & 43 &
\end{tabular}

In addition, 187 tourist surveys were conducted for this study to understand tourist expenditures on the Tárcoles Bridge and docks. Tourists surveyed on the Tárcoles Bridge and crocodile viewing tour docks were from 12 countries. Most of the people interviewed were from the United States (64\%), followed by Canada (13\%) as shown in Table 3. Apart from the two countries mentioned, other tourists were from various European countries (11\%). Only $3 \%$ of those interviewed were from Costa Rican. The low number of Costa Rican tourists was consistent with responses from informants with regard to domestic tourism; few Costa Rican stop at the bridge or pay for boat tours.

The results are consistent with information given by key informants who work in the tourism industry as to the different types of tourists they see at the bridge. As surveys were administered only in English or Spanish, any tourists who did not speak those languages were not interviewed. Due to the language limitation, there may be low representation from some countries. Also, many Asian visitors came in large guided tours of 20 or more people and it was not possible to include those groups in the surveys.

Almost half of respondents said they were staying in Costa Rica for 1 week (47\%), followed by $20 \%$ staying 2 to 3 weeks (Table 4 ) and $10 \%$ said they were day 
visitors coming from a cruise ship that had docked in Puerto Calderas. The cruise ship excursionists usually came in large groups (45 to 50 people) and were difficult to interview as their group guides would not give them sufficient time to respond to the research questions.

According to key informants that work at the various shops on the bridge and docks, the amount of money tourists spend depends on whether travelers are foreign (locals tend to not buy anything and consider these places "tourist traps") and whether or not the tourists are on the beginning or end of their trip. Key informants report that people tended to buy more towards the end of their trip as that may be their last chance to buy souvenirs before heading back to Puerto Calderas or San Jose.

Table 3: Nationality of Surveyed Tourists at Tárcoles Bridge and Docks

\begin{tabular}{|l|c|c|}
\hline \multicolumn{1}{c|}{ Country } & $\begin{array}{c}\text { Number of } \\
\text { Respondents }\end{array}$ & Relative Frequency \\
\hline Canada & 24 & $13 \%$ \\
\hline United States & 120 & $64 \%$ \\
\hline Costa Rica & 6 & $3 \%$ \\
\hline Spain & 10 & $5 \%$ \\
\hline Hungary & 1 & $1 \%$ \\
\hline Switzerland & 2 & $1 \%$ \\
\hline Brazil & 7 & $4 \%$ \\
\hline Italy & 2 & $1 \%$ \\
\hline Netherlands & 2 & $1 \%$ \\
\hline England & 4 & $2 \%$ \\
\hline Mexico & 3 & $2 \%$ \\
\hline No Response & 6 & $3 \%$ \\
\hline TOTAL & 187 & 1
\end{tabular}


Table 4: Length of Stay in Costa Rica of Surveyed Visitors to Tárcoles Bridge and Docks

\begin{tabular}{|l|c|c|}
\hline \multicolumn{1}{|c|}{ Length of Stay } & $\begin{array}{c}\text { Number of } \\
\text { Respondents }\end{array}$ & $\begin{array}{c}\text { Relative } \\
\text { Frequency }\end{array}$ \\
\hline 1 day & 18 & $10 \%$ \\
\hline 2-3 days & 26 & $14 \%$ \\
\hline 1 week & 88 & $47 \%$ \\
\hline 2-3 weeks & 37 & $20 \%$ \\
\hline 3-4 weeks & 1 & $1 \%$ \\
\hline 1+ month & 5 & $3 \%$ \\
\hline No Response & 6 & $3 \%$ \\
\hline N/A (lived in CR) & 6 & $3 \%$ \\
\hline TOTAL & 187 & $100 \%$ \\
\hline
\end{tabular}

The short visitor expenditure surveys were used to estimate the average expenditure per visitor per day in Tárcoles. Tourists were asked how much in US Dollars they spent on the bridge or docks (not including the crocodile tour if applicable). To avoid any confusion with currency exchange rates and to make it as easy as possible for tourists to answer financial questions, categories in increments of USD 4 were used when asking about visitor expenditures. Tourists were asked how much they spent on the bridge or docks and responses were then separated by the following scales: USD 0, USD 1-4, USD 5-9, USD 10-14, USD 15-19, USD 20-24, USD 25-30, or more than USD 31.

Analysis of the relative frequency of how much a single tourist would spend on the Tárcoles Bridge or docks, not including the crocodile viewing tour, if applicable, revealed that approximately $50 \%$ of tourists spent USD 5-14. For this reason, median expenditure of the typical tourist in Tárcoles was estimated to be USD 10. This was consistent with reports from key informants that work in nearby shops and food carts, who reported that the typical tourist would spend roughly USD 10 per person (Table 6). 
Table 5: Tourist Expenditures on Tárcoles Bridge or Docks (Not Including Crocodile Viewing Tour)

\begin{tabular}{|c|c|c|}
\hline $\begin{array}{c}\text { Amount Spent in } \\
\text { USD }\end{array}$ & $\begin{array}{c}\text { Number of } \\
\text { Respondents }\end{array}$ & $\begin{array}{c}\text { Relative } \\
\text { Frequency }\end{array}$ \\
\hline$\$ 0$ & 56 & $30 \%$ \\
\hline$\$ 1-4$ & 5 & $3 \%$ \\
\hline$\$ 5-9$ & 47 & $25 \%$ \\
\hline$\$ 10-14$ & 45 & $24 \%$ \\
\hline$\$ 15-19$ & 10 & $5 \%$ \\
\hline$\$ 20-24$ & 14 & $7 \%$ \\
\hline$\$ 25-29$ & 0 & $0 \%$ \\
\hline$\$ 30+$ & 4 & $2 \%$ \\
\hline No Response & 6 & $3 \%$ \\
\hline TOTAL & 187 & $100 \%$ \\
\hline
\end{tabular}

Because the Tárcoles Bridge has become a popular destination, one of the questions asked on the tourist survey concerned perceptions of safety for better management of the destination. The Tárcoles Bridge is located on the Carretera Pacifica where the highway crosses the Tárcoles River. At the point where the bridge is located, the highway is reduced to a 2-lane road where passenger cars and 18-wheel trucks transit. Tourists only have a 0.60 meter raised sidewalk to walk on and view crocodiles. During high season, as many as 40 people can be seen standing on each side of the bridge looking down at the river. Additionally, the bridge is not sturdy and while standing on the bridge sidewalk, one can feel the vibrations from oncoming traffic.

When asked, almost $80 \%$ of respondents said they felt safe on the current installations (Table 7). This contrasts with the perceptions of the shop owners and restaurant workers on the bridge. They felt there should be more precautions taken by the government or the ICT to ensure tourist safety. One parking attendant reported witnessing multiple occasions where tourists were almost hit by oncoming vehicles while crossing the bridge. 
Table 6: Relative Frequency of Tourist Responses to the Question "Do you feel safe on bridge or docks?"

\begin{tabular}{|c|c|c|}
\hline Responses to Question & Number of respondents & Relative Frequency \\
\hline Yes & 146 & $78 \%$ \\
\hline No & 35 & $19 \%$ \\
\hline No Response & 6 & $3 \%$ \\
\hline TOTAL & 187 & $100 \%$ \\
\hline
\end{tabular}

\subsection{Economic Impact of Crocodile Tourism}

Crocodile tourism in Tárcoles has 2 seasons: high and low. Several informants noted that these seasons are dictated by the average school and vacation calendars of the United States, as more tourists are from that country than any others, and by the cruise calendar from Port Calderas. The following months were considered high season: January, April, June, July, August, and December. Months for low season are: February, March, May, September, October, and November. From this, 184 days of the year 2014 were considered high season and 181 days of the year were considered low season.

As mentioned before, tourism sales were estimated for the following four categories: (1) souvenir and fruit stands on the Tárcoles Bridge, (2) restaurants on the Tárcoles Bridge, (3) crocodile tour operators in Tárcoles that are open year-round, and (4) crocodile tour operators in Tárcoles that do not operate year-round.

During the 184 days of the high tourist season in 2014, on average 500 people stop on the Tárcoles Bridge per day. Based on the range of tourist expenditures per day (Table 5), the DVE for souvenir and fruit stand sales are USD 704,260. During the 181 days of the low tourist season, on an average 200 people stop on the Tárcoles Bridge each day. Based on the range of tourist expenditures per day, the estimated direct sales for 
souvenir and fruit stand sales are USD 277,111. Therefore, the total estimated direct sales for the souvenir and fruit stand for the year 2014 are USD 981,371.

In addition to the souvenir shops and fruit stands there are 2 restaurants located on the Tárcoles Bridge. One is a large buffet-style restaurant with a capacity for 150 people and the other is a smaller a-la-carte restaurant with a capacity for 50 people. The larger restaurant estimates that 200 people visit per day during high season while 50 people visit per day during low season. The price per plate at this restaurant is USD 12 (CRC 6,000). For high season, the DVE is estimated to be USD 441,600. During low season, the DVE is estimated to be USD 108,600. Direct sales for 2014 for the larger restaurant is estimated at USD 550,200. The smaller-a-la-carte restaurant offers plates at different prices, the most popular being approximately USD 8 (CRC 4,000). During high season, an average of 50 people, and during low season an average of 20 people are served. The estimated direct sales is estimated at USD 73,600 for high season and USD 3,620 for low season. In total the estimated annual direct sales for 2014 for the smaller bridge-side restaurant is USD 77,220. While this may seem low, it is important to note that the owner of the smaller restaurant also owns the space where the souvenir and fruit stands are located, so profits from the restaurant are supplemented by the rent that is collected from the other establishments. Based on the tourist surveys, key informant interviews, the Tárcoles Bridge, the total direct sales to tourists is estimated at USD 1,608,791 for 2014.

In addition to viewing crocodiles on the bridge, many tourists take tours on the Tárcoles River to see the animals up close from boats. At the time this research was carried out, there were 5 crocodile viewing tour operators in Tárcoles but only two tour 
companies operate daily year-round. During high tourist season, they operate four tours daily each with typically, 50 people on board. The cost per tour for foreign tourists was USD 30 in 2014. Companies offer discounts and complimentary tickets for students or special circumstances but those are issued on an as-needed basis and they are therefore not predictable. The daily direct sales for crocodile viewing tours for the two companies that operate year-round during high season is estimated at USD 2,208,000. During low season the companies operate two tours per day (one in the morning one in the afternoon) with approximately ten people on board per trip. The daily direct sales for the tours during low season are estimated to be USD 217,200 for the two year-round operators.

The other three tour operators in Tárcoles conduct tours less frequently, with two operating exclusively on demand during the high tourist season. Information for the ondemand operators was difficult to obtain, but informants estimated that they run six tours a year each with groups of 6 people, charging USD 30 per ticket. Total direct sales for the on-demand companies are thus estimated to be USD 2,160. Another tour operator runs on-demand tours as well, but more frequently than the other two on-demand companies, and mostly during high season. This operator goes out approximately two times per day with an average of 20 people, and charges USD 30 per ticket. During high season, the total direct sales for this company is estimated to be USD 220,800.

Based on the approximations given by the tourism operators and other informants, the total direct sales to tourists from the crocodile viewing tours in Tárcoles is estimated at USD 2,430,960 for 2014. In total, the estimated direct sales of crocodile tourism in Tárcoles is USD 4,039,751 for 2014 (Table 7). 
Table 7: Estimated Direct Sales for 2014 in USD Businesses Associated with Crocodile Tourism in Tárcoles

\begin{tabular}{|c|c|}
\hline Category of Business & Estimated Direct Sales for 2014 in USD \\
\hline Souvenir and Fruit Stands & $981,371.00$ \\
\hline Restaurants & $627,420.00$ \\
\hline Year-round Tour Operators & $2,208,000.00$ \\
\hline Non Year-round Tour Operators & $222,960.00$ \\
\hline TOTAL & $4,039,751.00$ \\
\hline
\end{tabular}

The economic multiplier effect was calculated to understand the effect on money that enters the local economy through purchase of local goods and services, residential and commercial construction, and other expenditures. Type I multipliers were calculated by asking key informants to estimate the percentage of their revenue they spend on operating costs. An average of the percentages of the businesses interviewed were calculated by category (Table 8 ).

Table 8: Average Percentage of Operating Costs for Businesses Associated with Crocodile Tourism in Tárcoles

\begin{tabular}{|c|c|}
\hline Category of Business & $\begin{array}{c}\text { Average } \\
\text { Percentage } \\
\text { Operating Costs }\end{array}$ \\
\hline Souvenir and Fruit Stands & $22 \%$ \\
\hline Restaurants & $28 \%$ \\
\hline Year-round Tour Operators & $37 \%$ \\
\hline $\begin{array}{c}\text { Non Year-round Tour } \\
\text { Operators }\end{array}$ & $17 \%$ \\
\hline
\end{tabular}

To calculate the indirect sales, the average percentage of operating costs of each category was multiplied by their respective direct sales calculation from Table 7 (see Table 9). 
Table 9: Estimated Indirect Sales for Businesses Associated with Crocodile Tourism in Tárcoles

\begin{tabular}{|c|c|}
\hline Category of Business & Indirect Sales in USD \\
\hline Souvenir and Fruit Stands & $215,901.62$ \\
\hline Restaurants & $175,677.60$ \\
\hline Year-round Tour Operators & $816,960.00$ \\
\hline $\begin{array}{c}\text { Non Year-round Tour } \\
\text { Operators }\end{array}$ & $37,903.20$ \\
\hline
\end{tabular}

The estimated Type I multiplier for each category was calculated and the average Type I multiplier effect to measure the economic impact of crocodile tourism (Table 10).

Table 10: Type I Multiplier by Business Category Associated with Crocodile Tourism

\begin{tabular}{|l|r|c|r|}
\hline Category of Business & Direct Sales & Multiplier & Weight $^{1}$ \\
\hline Souvenir and Fruit Stands & 981,371 & 1.22 & 0.24 \\
\hline Restaurants & 627,420 & 1.28 & 0.16 \\
\hline Year-round Tour Operators & $2,208,000$ & 1.37 & 0.55 \\
\hline Non Year-round Tour Operators & 222,960 & 1.17 & 0.06 \\
\hline TOTAL & $4,039,751$ & & \\
\hline $\begin{array}{l}\text { Weighted Average Multiplier to } \\
\text { measure crocodile tourism in Tárcoles }\end{array}$ & & $\mathbf{1 . 3 1}$ & \\
\hline
\end{tabular}

${ }^{1}$ Weight represents the proportion of the direct sales of a given category to the Total Sales of all four categories combined.

To calculate the total estimated value of crocodile tourism in Tárcoles, Costa Rica, the average Type I weighted multiplier is applied to total direct sales. Therefore, the total estimated value of crocodile tourism in Tárcoles, Costa Rica in 2014 is USD $5,292,073.81$. 


\section{Discussion}

\subsection{Assumptions and Limitations}

Assumptions for this research are that tourists responded truthfully to expenditure surveys and that key informants were candid during their interviews. Given the short amount of time each tourist spent on the bridge, the travel cost model survey method was not used. Pre-testing of the tourist surveys by Heinen determined that shorter surveys would be more appropriate to use in this setting. Another limitation of the study are the types of tourists that were surveyed. Only people who spoke Spanish or English were approached for this research. Tourists from several Asian and European countries view crocodiles on the Bridge or go on crocodile viewing tours, but some could not be surveyed due to the language barrier.

Only expenditures on the Tárcoles Bridge and Tárcoles docks by the tourism operators were analyzed for this study. Although the town of Tárcoles has small shops, restaurants, and a hotel, almost all tourism activity based on crocodile viewing occurs at the Bridge and docks. Most tourists who stop on the bridge or go on tours do not stay in Tárcoles. With regard to the crocodile viewing tour operators, citing privacy and tax concerns, they did not share direct financial information with me thereby limiting the scope of the information. Instead tour companies estimated their number of clients and expenditures disaggregated by low and high tourist seasons in 2014. In addition, although nature based tourism is widely known and reported in Costa Rica, there is a lack of data available as it pertains to Tárcoles. This could be due to the informal nature of the activity (especially on the Tárcoles Bridge) and the size of the study area. 


\subsection{Crocodiles are part of Tárcoles's Cultural and Economy Identity}

This study provides insight on the economic and social impact of crocodile tourism in Tárcoles, Costa Rica. Over the years, many hundreds of thousands of tourists have visited the Tárcoles Bridge or the town of Tárcoles to view crocodiles in their natural habitat. Although crocodile viewing may not be the main reason for people to travel to Costa Rica, it is a must-see for tourists passing by on their way to the beaches of Jacó or Manuel Antonio National Park. Through tourist surveys, key informant interviews, reviews of secondary data, and other methods I estimated the economic value of crocodile tourism to better understand the tourism activity's impact on the area and what strengths exist for the conservation of the crocodiles.

C. acutus is ubiquitous in the Tárcoles region and is part of the town's cultural and economic identity. In the native Huetar language, Tárcoles means rough or bumpy skin, alluding to the skin of $C$. acutus found in great abundance in the area. The nearby Carara National Park is named after the Huetar word for "crocodile." C. acutus is part of Tarcoles's identity and many local shops and restaurants are named after the animal such as Cocodrilo Pizzeria (closed at the time the research was done, but signs for the establishment were still visible), Restaurante Ecologico Los Cocodrilos, Cabinas Los Cocodrilos, Crocodile Man Safari, Jungle Crocodile Safari and others. Moreover, crocodiles in Tárcoles are well known internationally. A simple online search of the keywords "Costa Rica Crocodile" leads to hundreds of results that point to C. acutus in Tárcoles. Because the Tárcoles Bridge is not an official tourist spot in the sense of the many well-advertised national parks, the fact that Tárcoles crocodiles are well known 
internationally and are part of the town's identity is a strength for the animals' conservation.

The town of Tárcoles has a history of being involved in tourism, per several informants. During the 1960s and 1970s, Tárcoles served as a small ferry port for people travelling from the capital, San Jose, to Jacó, a beach town in the Pacific Coast of Costa Rica. Small business such as restaurants and "cabinas" (small rooms for rent) sprang up to provide services to the travelers. However, after the Pacific Highway was built, it made the ferry route obsolete as it made travel times much faster between San Jose and Jacó. One informant compared Tárcoles to the town of Radiator Springs, a fictional town in the Disney movie "Cars" that was forgotten once Route 66 was built and bypassed the town. As per several key informants and documents, in the early 1990s, Colombian veterinarian and honorary member of the International Union of Conservation of Nature Species Survival Commission (IUCN-SSC) Crocodile Specialist Group Mario Fernando Orjuela Castro visited Tárcoles and saw a business opportunity with the abundance of crocodiles in the area. As an outsider, locals claim he saw potential for tourism in the river, whereas Costa Ricans thought it was too contaminated. In 1993, Orjuela founded the Jungle Crocodile Safari tour company with local business owner Victor Sergio Pineda Jaén, who also had experience handling crocodiles, in Tárcoles. Some informants claim that differences in management practices and personal issues led to a rift in the company causing the Pinedas to open their own company called Crocodile Man Tours. Today, both companies claim to be the "original crocodile tour." 
In all interviews with key informants that live in Tárcoles, the importance of $C$. acutus to their overall economy was stressed. Although Tárcoles was a fishing town traditionally, roughly half of those living in the town depend on tourism brought about by C. acutus. Several informants that grew up in the town reported that the tourism industry prevents "brain drain" and provides opportunities for individuals with higher education levels to remain. Because the tourism industry differs greatly from small scale fishing in terms of working schedules and skills, one key informant that works for a tour operator reported a change in attitudes throughout the town in terms of work ethic. When tourism workers or operators were asked if working in tourism was something they saw themselves doing for the rest of their lives, and something they would want for their children, they responded positively and some expressed hope that tourism would help their families gain social status.

The economic benefits derived from nature-based tourism is an important strength and incentive for C. acutus conservation in Tárcoles. Bringing in an estimated USD 4,039,751 in direct sales and USD 5,292,073.81 in indirect sales generates, in a town of approximately 6,000 total residents, tourism is a main economic driver and is central to the economic development of the region. Even more impressive is that these enterprises are run by locals, thereby limiting economic leakages. If crocodile tourism is to remain a mainstay in the area, there need to be plans for the sustainability of a healthy crocodile stock for tourists to see. As Tárcoles is not an official tourist destination like Jacó or Manuel Antonio National Park, if the crocodiles are no longer there or if the Tárcoles 
River is not clean, tourists will most likely still visit Costa Rica, but not spend any money in the Tárcoles region.

\subsection{Crocodile Tourism is Ecotourism Lite}

Terms such as "nature-based tourism", "nature tourism", and "ecotourism" are sometimes used interchangeably in marketing and describing tourism activities. It is important to clarify that not all nature-based tourism can be classified as ecotourism. In the case of crocodile tourism in Tárcoles, this type of tourism should be classified as nature-based tourism or "eco tourism lite" (Honey, 2008). During the time this research was conducted, the environmental and cultural awareness and education at the crocodile viewing site and on tours was little to nonexistent. At the Tárcoles Bridge there were no educational materials despite it being a major tourist stop. In 2015 a new sign was posted at the bridge to warn tourists about the animals below, but no information on their ecology or the ecosystem was provided. During some of the feeding and viewing tours, tourists are given more information about the animals and their surroundings. Tourists on boat tours are given an animal identification sheet with several species that are found in the area in several languages and some information about the Tárcoles River. Understandably, because the tour is only roughly an hour and a half long, boat tour guides do not have to opportunity to give in depth explanations of the ecosystem. Notwithstanding, the type of tourist that usually visits Tárcoles is generally not particularly interested in a full immersive experience, but rather a "lite" tour in nature to see guides feed crocodiles. 
Another reason why crocodile tourism in Tárcoles is not true "ecotourism" based on recent definitions is that, although crocodile tourism provides financial benefits to the local community, it does not provide direct financial benefits for conservation. During the time this research was carried out no direct schemes for financing crocodile or ecosystem conservation was identified. The two main tourism operators claimed to participate in sporadic, voluntary river clean ups organized by local schools or the Red Cross, but these are not concerted long term efforts. To take care and clean up the Tárcoles River is to ensure $C$. acutus's viability in the area and the long-term sustainability of the crocodile tourism industry.

\subsection{Externalities}

Tourism activities impact the areas where they take place in the form of myriad externalities. It is often difficult to assess the numerous side effects associated with tourism, particularly the non-economic ones, as no markets for them exist. Because of this, decisions on how to deal with externalities can lead to individual decisions that are not optimal for a society. Crocodile tourism has impacted Tárcoles in many ways, positive and negative. For example, increased attention to the area has brought more visibility and tourist traffic to Tárcoles, however, in the case of the Tárcoles Bridge, tourists are now at more risk of oncoming traffic. Figure 2 shows four categories of impacts and the positive and negative externalities. 
Figure 2: Negative and Positive Externalities of Crocodile Tourism in Tárcoles

\begin{tabular}{|c|c|c|}
\hline Category & Positive Externality & Negative Externality \\
\hline Livelihood & $\begin{array}{l}\text { Improved employment options for locals with } \\
\text { higher salaries and stability makes local stay in } \\
\text { Tárcoles. } \\
\text { Tourism income stays in the region because the } \\
\text { management of operations is local. }\end{array}$ & $\begin{array}{l}\text { There is heavy competition between the two main tourism } \\
\text { operators in Tárcoles, which causes negative social impacts. } \\
\text { There is a stark contrast between locals who work in the tourism } \\
\text { industry and the fishing industry. Those who work in tourism have } \\
\text { better cars, motorcycles, etc. }\end{array}$ \\
\hline Environment & $\begin{array}{l}\text { Increase attention to crocodile tourism has } \\
\text { brought awareness of the state of the Tárcoles } \\
\text { River. } \\
\text { Because of the economic value they represent to } \\
\text { the area, there is an incentive to protect } \\
\text { crocodiles and their ecosystem. }\end{array}$ & $\begin{array}{l}\text { Crocodile feeding tours may have affected crocodiles' behavior } \\
\text { and health. } \\
\text { Increase in tours and people who stop on the Tárcoles Bridge } \\
\text { adds more pollution from boats, hotels, restaurants, buses, and } \\
\text { others. } \\
\text { Crocodile feedings may lead to the largely territorial animals } \\
\text { congregating in high numbers in smaller areas therefore } \\
\text { increasing the possibility of people-crocodile conflicts and } \\
\text { conflicts amongst the crocodiles themselves. }\end{array}$ \\
\hline
\end{tabular}

Human-wildlife conflicts of many types are common worldwide (e.g. Shrivastava and Heinen, 2007) and few animals elicit stronger responses in humans than large predators. But, of the 23 or 24 living crocodilian species (taxonomies vary), only eight are known to attacks humans unprovoked. Of them, attacks by the Saltwater (C. porosus) and Nile Crocodiles (C. niloticus), as well as American Alligators (A. mississippiensis), are best known. Less commonly implicated are: Black Caiman (M. niger), Morelet's Crocodile (C. moreletii), Mugger Crocodile (C. palustris), American Crocodile $(C$. acutus) and Gharial (G. gangeticus). Due to growing populations of crocodilians in many places, and growing human populations, human/crocodile conflicts are increasing. Reasons for attacks vary by species, but experts stipulate that crocodiles are most dangerous during breeding season and many attacks are in defense of territories or nests. 
Simple cases of mistaken prey identity are also implicated in some recent attacks, including several by American Crocodiles in Mexico and Costa Rica in which surfers or swimmers were bitten by large adults, but quickly released. Other cases are definitely predatory, but they are mostly associated with Nile and Salt Water Crocodiles. Those two species are estimated to kill many hundreds to several thousands of people annually (e.g. CrocBITE, 2017).

Despite Costa Rica's small size, the country has the second highest number of $C$. acutus related incidents reported in the world (CrocBITE, 2017). Given that high concentrations of $C$. acutus are found in the Tárcoles River, it is no surprise that conflicts between people and crocodiles exist in the area. Human/crocodile conflicts that garner the most media and local attention in Tárcoles are those involving fatalities. During the time this research was conducted (2012 to 2016), three human fatalities were reported in Costa Rica as the result of encounters with C. acutus (CrocBITE, 2017) and two were in Tárcoles. The most recent attack occurred in 2015 when an inebriated individual either fell or jumped into the river and was killed by crocodiles. The incident was widely reported and is noteworthy because many in the crocodile tourism industry attribute it to be responsible for the increased attention from the Costa Rican government on their operations.

Crocodiles were also on the receiving end of fatalities in the region due to interactions with humans. In 2015, five large crocodiles were found decapitated on beaches in Tárcoles. All were found with their heads chopped off, presumably, for sale as trophies. Another publicized people-crocodile conflict was a report from a local news 
station that a man was selling crocodile kabobs from the Tárcoles Bridge to tourists. I interviewed the man in question and he revealed the story was a hoax. Other workers on the bridge and in the area confirmed that the man's story was false and therefore no legal actions were taken against him. However, the man's false claims did capture the attention of the public.

In addition, the feeding of crocodiles could alter their behavior, as has been reported for other wildlife species in close proximity to tourists (King and Heinen, 2004). The tour operators feel that the feeding tours do not harm or have negative effects on the crocodiles. However, studies have shown that feedings and interactions with tourists can impact many wild species (Orams, 2002). Donier et al. (1997) showed that, with supplemental feeding from tourists, animals typically spend less time foraging and hunting and thus have more time to dedicate to other activities such as socializing or traveling. Feeding by tourists may also affect the extent of an individual's home range (Boutin, 1990), increase breeding activity, group size (Lindsey, 1988) and/or population density (Gilbert and Krebs, 1981). Additionally, studies have shown that the feeding of wildlife for tourism purposes can change certain behaviors such as migration patterns (Paton et al., 1983), or alter the composition of animal communities where larger, more aggressive individuals become more abundant locally, as they are better able to access food provided by humans. Studies need to be conducted to see if tourism activity has altered crocodile behavior in Tárcoles. Crocodile densities just below the bridge, for example, are observably much higher than along all other stretches of the river. 
Many farms and cattle ranches are located near the town of Tárcoles and along the river and therefore present potential concerns about crocodiles. The owner of a restaurant on the Tárcoles Bridge is a member of a cattle ranching and landowning family in the area. He stated that crocodiles do not pose significant threats to cattle or farmers. Locals who live or work on ranches and farms know not to bring calves into riparian zones and crocodiles have taken very few cattle in the region according to that restaurant owner and other key informants. Interestingly, when asked about why he left cattle ranching, he claimed it is was more economically viable to run a tourist establishment than to raise cattle. This individual also owns much of the land near the bridge and he rents it out for souvenir and other shops.

\subsection{Conclusions}

Costa Rica is a world-renowned tourist destination where tourists flock every year to experience its natural wonders. In 2015, over 2.6 million tourists arrived in Costa Rica and $72.9 \%$ of those cited vacation as their principle motive for traveling (ICT, 2016). While many foreign chain-style hotels and tourism enterprises have increased their presence in Costa Rica, crocodile tourism in Tárcoles is locally run thus making it unique. Located on the Pacific, the small town of Tárcoles is famous for its crocodile tours where tourists can have close encounters with these fearsome giants. Given the value of the industry, and the fact that many residents of the town of Tárcoles take part, crocodile tourism in the region provides many direct economic benefits and, given the importance of crocodiles in the local region, it should provide some social incentives in the form of local pride in support of conserving crocodiles (e.g., Low and Heinen, 1993; 
Heinen, 1994). But it is also likely that most people in the region are not aware of the large economic impact and my study is the first that I know of in which an estimation was attempted. Thus, community outreach and environmental awareness/education programs would doubtlessly be beneficial and, hopefully, reduce events such as the recent slaughter of several adult crocodiles for their heads, as described above.

Hundreds of tourists congregate at the Tárcoles Bridge daily year-around to view crocodiles gathered below and many embark upon viewing tours in the Tárcoles River, thus making C. acutus the main tourist attraction in the area. For this reason, crocodile conservation is important for the local economy. An asset that can be used to advocate for crocodile conservation is that $C$. acutus is part of the cultural and economic identity. Many shops and restaurants in Tárcoles and the region have "crocodile" in their name. There is an opportunity to use $C$. acutus as a flagship species to promote conservation to the public (Mittermeier, 1986, 1987; Western, 1987). The image of a flagship species helps focus the abstract idea of "conservation" to the broader public and helps to make it tangible. River clean up campaigns and/or educational programs can be organized around the idea of conserving crocodiles and their environment.

At the time this research was carried out, there were no initiatives aimed at crocodile or river conservation in the Tárcoles area. Although the crocodile tourism industry has brought new economic opportunities and life to Tárcoles, there is no longterm investment by tour operators or the local or national governments for river conservation and crocodile tourism does not provide direct financial benefits in support of conservation. To ensure the sustainability of the $C$. acutus population in the area, 
conservation and pollution mitigation strategies should to be employed. Protection of the ecosystem and the animals would ensure the sustainability of crocodile tourism.

Until recently the legal framework that protects $C$. acutus in Costa Rica, the Ley de Vida Silvestre, was not enforced on crocodile tour operators or the locals who work on the Tárcoles Bridge. During the time this research was conducted, tours on the Tárcoles River included the hand feeding of crocodiles by tour guides and even allowed for tourists to touch crocodiles. The surge in attention from the media about conflicts with crocodiles (i.e. several human and crocodile deaths) in Tárcoles has led to increased enforcement. Towards the end of 2015, the MINAE (Ministro de Ambiente y Energia) and SINAC (Sistema Nacional de Áreas de Conservación) met with tourism operators to discuss phasing out crocodile feeding tours, but operators need assurances that the law will be applied fairly to all parties, regardless of the owner's country of origin or standing in the community. Feeding from the bridge may be more difficult to control given that people stop all day long and many bring fish or other meat to feed the crocodiles below.

An interesting and important area for future study is to understand what effect the phasing out of feeding tours would have on crocodiles and the preferences of tourists. If crocodiles that were habituated are no longer fed, will they move elsewhere in the river or will they stay? If crocodiles move, how will this affect tourism? Many tourists decide to spend their money and time on crocodile tours because of the aspect of being able to see these magnificent creatures up close while being fed. If the feedings stop, will tourists skip this activity all together? These are important questions that should be investigated to understand how these changes may affect the economic viability of crocodile tourism. 
Some informants felt that there has been an increase in the $C$. acutus population in the area. There is anecdotal evidence of sightings of crocodiles where previously there were none. While an increase in population of a once-threatened species is positive, the high concentrations in the region has led to increased conflicts with humans. Even though local fishermen interviewed here did not report competition with crocodiles for fish, many locals felt threatened by their presence and abundance. This has been exacerbated by reports in the local media and online popular journals of surfers and beachgoers encountering crocodiles with several attacked.

The recent spotlight on Tárcoles and its resident crocodiles has started a debate amongst local people as to whether hunting of $C$. acutus should be allowed to control the population. Some local Tárcoles residents who were interviewed and who were not involved in crocodile tourism expressed negative perceptions of crocodiles and felt that, while the animals have always lived in the river, the population was increasing too fast. They felt that if the C. acutus population continues to increase the Costa Rican government should step in and manage the animals and several advocated for controlled hunting. A population census should be done to confirm or dismiss these perceptions and a management plan should be created to that addresses these concerns.

People have always been fascinated by animals and throughout history many societies have had close relationships with them. Given the connection humans have with animals, it is no surprise that getting close to animals is a popular tourist attraction and at many times wildlife encounters are at the center of the tourist visit. Viewing an apex predators, whether they be sharks, tigers or crocodiles, adds adventure to any vacation 
and, if done sustainably and correctly, can benefit the communities where the activity takes place and enhance conservation. The present research is a first step in understanding the social and economic impact of crocodile tourism in Tárcoles. There is a need for further research given the changing legal landscape surrounding this activity. 


\section{Bibliography}

Aguirre, J. A. (2008). Midiendo el impacto economico del gasto turistico de los visitantes a los parques nacionales de costa rica. Pasos: Revista De Turismo y Patrimonio Cultural, 6(1), 11-26.

Baillie, J. E. M., Hilton-Taylor, C., \& Stuart, S. N. (2004). 2004 IUCN red list of threatened species: A global species assessment. Gland: IUCN.

Baral, N. and J.T. Heinen. 2006. The Maoist People's War and conservation in Nepal. Politics and the Life Sciences 24(1-2),1-11.

Baral, N., Kaul, S., Heinen, J. T., \& Ale, S. (in press). Estimating the value of World Heritage Site designation: A case study from Sagarmatha (Mt Everest) National Park, Nepal. Journal of Sustainable Tourism.

Berle, P. (1990). Two faces of ecotourism. Audubon, 92(2), 6.

Bernard, H. R. (2011). Research methods in anthropology: Qualitative and quantitative approaches. Lanham, Md.: AltaMira Press.

Bhat, M. G., Bhatta, R., \& Shumais, M. (2014). Sustainable funding policies for environmental protection: The case of Maldivian atolls. Environmental Economics and Policy Studies 16(1), 45-67.

Bhatt, S., \& Liyakhat, S. (2008). Ecotourism development in India. communities, capital and conservation. New Delhi: Centre for Environment Education and Cambridge University Press.

Billgren, C., \& Holmen, H. (2008). Approaching reality: Comparing stakeholder analysis and cultural theory in the context of natural resource management. Land use Policy, 25(4), 550-562. doi:10.1016/j.landusepol.2007.11.004

Blomquist, W., Ballestero, M., Bhat, A., \& Kemper, K. (2005). Institutional and Policy Analysis of River Basin Management: The Tárcoles River Basin, Costa Rica. Policy Research Working Paper; No. 3612. World Bank, Washington, DC. (C) World Bank. https://openknowledge.worldbank.org/handle/10986/8232 License: CC BY 3.0 Unported.

Boutin, S. (1990). Food supplementation experiments with terrestrial vertebrates patterns, problems, and the future. Canadian Journal of Zoology-Revue Canadienne De Zoologie, 68(2), 203-220. doi:10.1139/z90-031

Brendon, P. (1991). Thomas cook: 150 years of popular tourism. London: Secker (Martin) \& Warburg Ltd. 
Campbell, L. (2002). Conservation narratives in Costa Rica: Conflict and co-existence. Development and Change, 33(1), 29-56. doi:10.1111/1467-7660.00239

Ceballos-Lascurain, H. (1996). Tourism, ecotourism and protected areas: The state of nature-based tourism around the world and guidelines for its development. Gland, Switzerland \& Cambridge, UK: IUCN.

Central Intelligence Agency (CIA). (2017). The World Factbook: Costa Rica. Retrieved from https://www.cia.gov/library/publications/the-world-factbook/geos/cs.html

Chase, G., \& Alon, I. (2002). Evaluating the economic impact of cruise tourism: A case study of Barbados. Anatolia, 13(1), 5-18.

Christ, C. (2003). Tourism and biodiversity- mapping tourism's global footprint. Washington, DC: Conservation International.

Collins, D., \& Tisdell, C. (2002). Age-related lifecycles - purpose variations. Annals of Tourism Research, 29(3), 801-818. doi:10.1016/S0160-7383(01)00081-0

Creswell, J. W., \& Plano, C. V. L. (2011). Designing and conducting mixed methods research. Los Angeles: SAGE Publications.

CrocBITE. (2017). Crocodile attack simple search. Retrieved from http://www.crocodileattack.info/data/filter-simple

Donier, E. R., DelGiudice, G. D., \& Riggs, M. R. (1997). Effects of winter supplemental feeding on browse consumption by white-tailed deer. Wildlife Society Bulletin, (25), $235-243$.

Duffus, D. A., \& Dearden, P. (1990). Non-consumptive wildlife-oriented recreation: A conceptual framework doi:http://dx.doi.org/10.1016/0006-3207(90)90087-6

Eade, C. (2011). Costa Rica? the perfect destination for adventure seekers, wildlife fans and lovers of rolling green hills- 'pura vida' indeed". Retrieved from http://www.dailymail.co.uk/travel/article-1341888/Costa-rica-holidays-the-perfectdestination-adventure-seekers-wildlife-fand.html\#ixzz1 pabqca1x

Evans, S. 2010. The Green Republic: A conservation History of Costa Rica. Austin: University of Texas Press.

Fennell, D. A. (2015). In Hall, M Gossling, S Scott,D. (Ed.), Tourism and the precautionary principle in theory and practice. Abingdon; 2 Park Sq, Milton Park, Abingdon Ox14 4rn, Oxford, England: Routledge. 
Fish, T. E. 2009. Assessing economic impacts of national parks. Park Science 26(2):20, 57. Available at https://www.nature.nps.gov/ParkScience/archive/PDF/Article_PDFs/ ParkScience26(2)Fall2009_20_57_Fish_2634.pdf.

Garcia Lozano, A. J., \& Heinen, J. T. (2016a). Property relations and the co-management of small-scale fisheries in Costa Rica: Lessons from marine areas for responsible fishing in the gulf of Nicoya. Marine Policy, 73, 196-203.

Garcia Lozano, A. J., \& Heinen, J. T. (2016b). Identifying drivers of collective action for the co-management of marine fisheries in the Gulf of Nicoya, Costa Rica. Environmental Management, 57(4), 759-769.

Ghate, R. (2003). Global gains at local costs: Imposing protected areas: Evidence from central India. International Journal of Sustainable Development and World Ecology, 10(4), 377-389.

Gilbert, B. S., \& Krebs, C. J. (1981). Effects of extra food on peromyscus and clethrionomys populations in the southern Yukon. Oecologia, 51(3), 326-331. doi:10.1007/BF00540901

Gunn, C. A., \& Var, T. (2002). Tourism planning: Basics, concepts, cases Psychology Press.

Gursoy, D., Chi, C. G., \& Dyer, P. (2009). An examination of locals' attitudes. Annals of Tourism Research, 36(4), 723-726.

Hearne, R. R., \& Salinas, Z. M. (2002). The use of choice experiments in the analysis of tourist preferences for ecotourism development in Costa Rica. Journal of Environmental Management, 65(2), 153-163.

Heinen, J. T. (1990). The design and implementation of a training program for tour guides in Royal Chitwan National Park, Nepal. Bangkok: FAO. Tiger Paper 17(2), 11-15.

Heinen, J. T. (1994). A behavioral ecological perspective on the issue of garbage. Human Ecology Review 1(1), 56-61.

Heinen, J. T. (1995a). Thoughts and theory on incentive-based programs to promote endangered species conservation in the United States. Wildlife Society Bulletin 23(3), 338-345.

Heinen, J. T. (1995b). International Conservation Agreements. pp. 375-384 $\underline{\text { In }}$ Nierenberg, W.A. (ed). Encyclopedia of Environmental Biology (Volume 1). San Diego: Academic Press. 
Heinen, J. T. (1995c). Nature Preserves. pp. 551-561 In Nierenberg, W.A. (ed). Encyclopedia of Environmental Biology (Volume 2). San Diego: Academic Press.

Heinen, J. T. (2010). The importance of a social science research agenda in the management of protected natural areas, with selected examples. Botanical Review, 76(2), 140-164. doi:10.1007/s12229-010-9043-y

Heinen, J. T. 2012. International Trends in protected areas policy and management. InTech, Chapter 1 in: www.intechopen.com (doi 10.5772/50061). Global Issues and Trends in the Protection of Natural Areas. 18 pp.

Heinen, J. T., Roque, A. \& Collado-Vides, L. C. (2017). Managerial Implications of Perceptions, attitudes and awareness of residents regarding the Puerto Morelos National Marine Park, Mexico. Journal of Coastal Research 33(2), 295-303.

Heinen, J. T., Shukurov, E. \& Sadykova, C. (2001). Legislative and policy initiatives in biodiversity conservation in Kyrgyzstan. Post Soviet Geography and Economics 42(7), 519-543.

Heinen, J.T. \& Thapa, B. B. (1988). A feasibility study of a proposed trekking trail in Chitwan National Park. Kathmandu: Tribhuvan University. Journal of the Forestry Institute, Nepal, 10, 19-28.

Hetzer, N. D. (1965). Environment, tourism, culture. Reported Ecosphere, 1-3.

Honey, M. (2008). Ecotourism and sustainable development: Who owns paradise? Island Press.

Hotelling, H. (1949). "Letter." in an economic study of the monetary evaluation of recreation in the national parks. Washington, DC: National Park Service.

Instituto Costarricense De Turismo (ICT). (2016). Estimación del porcentaje de turistas que realizaron los siguientes grupos de actividades período 2014-2015.

Jamal, T., \& Stronza, A. (2009). Collaboration theory and tourism practice in protected areas: Stakeholders, structuring and sustainability. Journal of Sustainable Tourism, 17(2), 169-189. doi:10.1080/09669580802495741

King, J. M., \& Heinen, J. T. (2004). An assessment of the behaviors of overwintering manatees as influenced by interactions with tourists at two sites in central Florida. Biological Conservation, 117(3), 227-234. doi:10.1016/j.biocon.2003.07.001

Kuenzi, C., \& McNeely, J. (2008). Nature-based tourism. Global risk governance (pp. 155-178) Springer. 
Lindsey, S. L. (1988). The effect of food availability on the social organization and behaviour of captive coyotes (Canis latrans). Dissertation Abstracts International B Sciences and Engineering, 48(8), 2233-2233.

Low, B. S. \& Heinen, J. T. (1993). The environment: Everybody's talking about it, but... Michigan Quarterly Review 32(1), 338-349.

Mazzotti, F. J., Best, G. R., Brandt, L. S., \& Cherkiss, M. S. (2009). Ecological Indicators, B 9(6), S137-S149.

Miller, A. (2012). Ecotourism development in Costa Rica: The search for Oro Verde New York: Lexington Books.

Mittermeier, R. A. (1986). Strategies for the conservation of highly endangered primates. Primates: The Road to Self-Sustaining Populations; Conference, San Diego, California, USA. 1013-1022.

Mittermeier, R., Oates, J., Struhsaker, T., Demello, M., Coimbra, A., Rylands, A., Dietz, L. (1987). Primate conservation - issues and strategies. International Journal of Primatology, 8(5), 406-406.

Murphy, P. E. (1983). Perceptions and attitudes of decision making groups in tourism centers. Journal of Travel Research, 21(3), 8-12.

Negi, C., \& Nautiyal, S. (2003). Indigenous peoples, biological diversity and protected area management - policy framework towards resolving conflicts. International Journal of Sustainable Development and World Ecology, 10(2), 169-179.

Nelson, J. (1994). The spread of ecotourism - some planning implications. Environmental Conservation, 21(3), 248-255.

Orams, M. B. (2002). Feeding wildlife as a tourism attraction: A review of issues and impacts. Tourism Management, 23(3), 281-293. doi:10.1016/S0261-5177(01)00080-2

Paton, D. C., Dorward, D. F., \& Fell, P. (1983). Thiamine-deficiency and winter mortality in red wattlebirds, anthochaera-carunculata (aves, meliphagidae) in suburban melbourne. Australian Journal of Zoology, 31(2), 147-154. doi:10.1071/ZO9830147

Ponce-Campos, P., Thorbjarnarson, J. \& Velasco, A. (2012). Crocodylus acutus. the IUCN red list of threatened species 2012. Retrieved from http://www.iucnredlist.org/details/5659/0 
Post, G. (2010). Evaluation of tiger conservation in India: The use of comparative effectiveness research. (Unpublished Masters of Environmental Management degree). Duke University,

Reid-Grant, K. \& Bhat, M. G. (2009). Financing marine protected areas: An exploratory study. Marine Policy 33(1),128-136.

Ryan, C., \& Harvey, K. (2000). Who likes saltwater crocodiles? Analysing sociodemographics of those viewing tourist wildlife attractions based on saltwater crocodiles. Journal of Sustainable Tourism, 8(5), 426-433. doi:10.1080/09669580008667377

Segura, G. (1998). Comentarios acerca de la campana de promocion turistica de costa rica en los estados unidos, 1996-1997. INCAE Publicacion CEN 652,

Sekercioglu, C. (2002). Impacts of birdwatching on human and avian communities. Environmental Conservation, 29(3), 282-289. doi:10.1017/S0376892902000206

Shrestha-Acharya, R., \& Heinen, J. T. (2006). Emerging policy issues on non-timber forest products in Nepal. Himalaya 26(1-2), 51-54.

Shrivastava, R. J., \& Heinen, J. T. (2007). A microsite analysis of communities around Kaziranga National Park, India: Implications for conservation and development. Journal of Environment and Development 16, 207-216.

Sistema Nacional de Areas de Conservacion de Costa Rica. (2012). Ley de conservación de la vida silvestre $\mathrm{N}^{\circ} 7317$ Ley de conservación de la vida silvestre $\mathrm{N}^{\circ} 7317$.

Stem, C., Lassoie, J., Lee, D., Deshler, D., \& Schelhas, J. (2003). Community participation in ecotourism benefits: The link to conservation practices and perspectives. Society \& Natural Resources, 16(5), 387-413. doi:10.1080/08941920390190041

Stynes, D. J., Propst, D. B., Chang, W. H., \& Sun, Y. (2000). Estimating regional economic impacts of park visitor spending: Money Generation Model Version 2 (MGM2). Department of Park, Recreation, and Tourism Resources; Michigan State University; East Lansing, Michigan, USA.

Ter-Ghazaryan, D., \& Heinen, J. T. (2006). Reserve management during transition: The case of Issyk-kul Strict Nature and Biosphere Reserve, Kyrgyzstan. Environmental Practice 8(1), 11-22.

The International Ecotourism Society (TIES). (2015). What is Ecotourism?. Retrieved from https://www.ecotourism.org/what-is-ecotourism 
Thorbjarnarson, J., Mazzotti, F., Sanderson, E., Buitrago, F., Lazcano, M., Minkowski, K., Velasco, A. (2006). Regional habitat conservation priorities for the American crocodile. Biological Conservation, 128(1), 25-36.

doi:http://dx.doi.org/10.1016/j.biocon.2005.09.013

Tisdell, C., \& Wilson, C. (2012). Nature-based tourism and conservation: New economic insights and case studies. Cheltenham; Glensanda House, Montpellier Parade, Cheltenham G150 1ua, Glos, England: Edward Elgar Publishing Ltd.

Towner, J. (1985). The grand tour doi:http://dx.doi.org/10.1016/0160-7383(85)90002-7

Towner, J., \& Wall, G. (1991). History and tourism

doi:http://dx.doi.org.ezproxy.fiu.edu/10.1016/0160-7383(91)90040-I

United Nations World Tourism Organization (UNWTO). (2016). UNWTO tourism highlights, 2016 edition. doi:10.18111/9789284418145

Wesson, Robert. (1984). Democracy in Latin-America - promise and problems -Annals of the American Academy of Political and Social Science, 475(SEP), 190-191.

doi:10.1177/0002716284475001028

Western, D. (1987). Africa elephants and rhinos - flagships in crisis. Trends in Ecology \& Evolution, 2(11), 343-346. doi:10.1016/0169-5347(87)90112-1

World Travel \& Tourism Council (WTTC). (2015). Travel \& tourism economic impact 2015 Costa Rica. (https://www.wttc.org//media/files/reports/economic\%20impact\%20research/countries\%202015/costarica2015. pdf)

Yeoman, I., Brass, D., \& McMahon-Beattie, U. (2007). Current issue in tourism: The authentic tourist. Tourism Management, 28(4), 1128-1138.

doi:10.1016/j.tourman.2006.09.012 